\title{
Temporomandibular joint disorders diagnosis and management- what does the future hold?
}

There are a number of contemporary clinical and research journal articles, chapters and books that address the past and present tools used for the diagnosis and management of temporomandibular joint disorders. Hopefully, the profession has learned enough about past diagnostic and management foibles and failures from that literature so that practitioners do not repeat them and can move on to a more enlightened future.

In light of all the recent advances in the biomedical sciences, we as guest editors felt that a special FOMM series dedicated to the future of TMJ diagnosis and management might be an excellent opportunity to examine where we might, or at least should be, looking at the tools we use and how we might improve those tools for the diagnosis and management of both extra-articular and intra-articular TMJ disorders in the future.

To accomplish this goal, invited authors were chosen for their interest, expertise, and research relative to their assigned topic. Each expert was asked to provide an evidence-based review of a specific topic culminating in their educated prognostication as to what should be pursued to assure increased TMJ disorder diagnostic and management capabilities for patients in the future. As guest editors, we strongly feel the content of this FOMM series will make a significant addition to the body of knowledge relative to TMJ disorders while serving as a catalyst to encourage further research in this field.

The main objectives for this special series:

(I) Based on the present evidence-based literature and research, what may be some improvements and enhancements for the management of extra-articular temporomandibular disorder (TMD)?

(II) Based on the present evidence-based literature and research, what may be some improvements and enhancements for the management of intra-articular TMD?

(III) Serve as a catalyst to encourage further investigative and research activities in the diagnosis, management, both medically and surgically, in TMD.

As guest editors, we thank the contributing authors for their time, expertise and excellent articles and prognostications.

\section{Acknowledgments}

Funding: None.

\section{Footnote}

Provenance and Peer Review: This article was commissioned by the editorial office, Frontiers of Oral and Maxillofacial Medicine, for the series “Temporomandibular Joint Disorders Diagnosis and Management - What Does the Future Hold?”. The article did not undergo external peer review.

Conflicts of Interest: Both authors have completed the ICMJE uniform disclosure form (available at https://fomm.amegroups. com/article/view/10.21037/fomm-2020-tjddm-12/coif). The series "Temporomandibular Joint Disorders Diagnosis and Management - What Does the Future Hold?” was commissioned by the editorial office without any funding or sponsorship. SEF and LGM served as the unpaid guest editors of the series. SEF serves as an unpaid editorial board member of Frontiers of Oral and Maxillofacial Medicine from Aug 2019 to Jul 2021. SEF reports other from Tissue Regeneration Systems, outside the submitted work; In addition, SEF has a patent United States Patent 8,275,594 licensed to Depuy/Syntheses, a patent United States Patent 8,478,422 issued, and a patent United States Patent 9,943,410 issued. LGM reports personal fees from TMJ Concepts, other from TMJ Concepts, outside the submitted work.

Ethical Statement: The authors are accountable for all aspects of the work in ensuring that questions related to the accuracy or integrity of any part of the work are appropriately investigated and resolved. 
Open Access Statement: This is an Open Access article distributed in accordance with the Creative Commons AttributionNonCommercial-NoDerivs 4.0 International License (CC BY-NC-ND 4.0), which permits the non-commercial replication and distribution of the article with the strict proviso that no changes or edits are made and the original work is properly cited (including links to both the formal publication through the relevant DOI and the license). See: https://creativecommons.org/ licenses/by-nc-nd/4.0/.

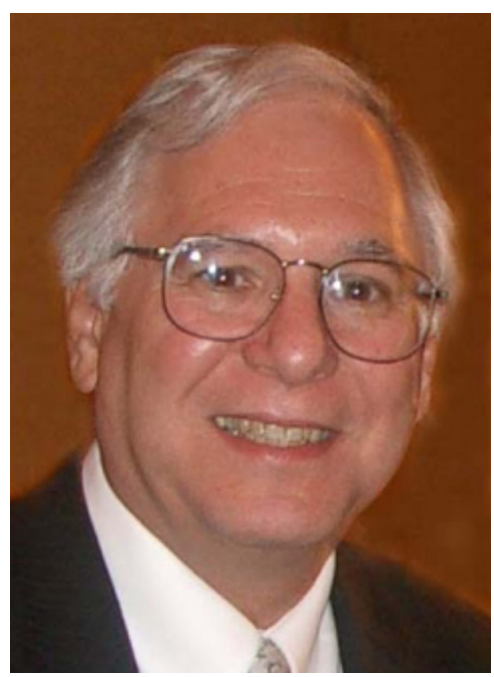

Stephen E. Feinberg

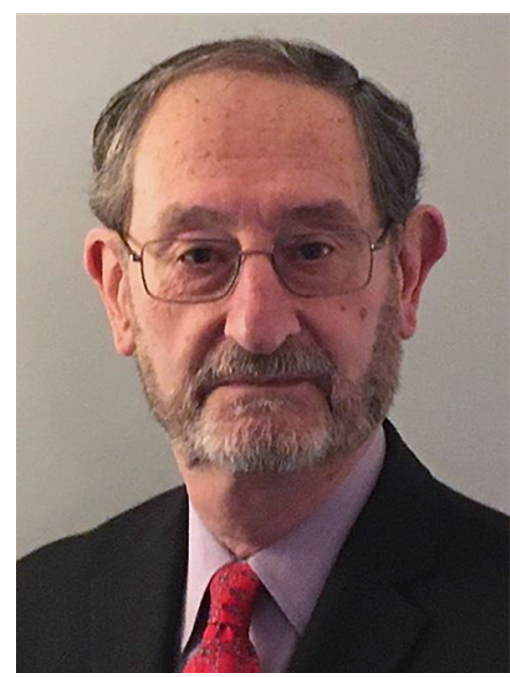

Louis G. Mercuri

Stephen E. Feinberg, DDS, MS, $\mathbf{P h D}^{1,2}$

${ }^{1}$ Department of Oral and Maxillofacial Surgery, University of Michigan School of Dentistry, Ann Arbor, Michigan, USA; ${ }^{2}$ Section of Oral and Maxillofacial Surgery, Department of Surgery, Michigan Medicine, Ann Arbor, Michigan, USA.

(Email:sefein@umich.edu)

Louis G. Mercuri, DDS, $\mathbf{M S}^{3,4,5}$

${ }^{3}$ Department of Orthopaedic Surgery, Rush University Medical Center, Chicago, Illinois, USA $;{ }^{4}$ Department of Bioengineering, University of Illinois Chicago, Chicago, Illinois, USA; ${ }^{5}$ TMF Concepts, Ventura, California, USA.

(Email:lgm@tmjconcepts.com)

Received: 29 September 2020; Accepted: 10 October 2020; Published: 29 October 2020.

doi: $10.21037 /$ fomm-2020-tjddm-12

View this article at: http://dx.doi.org/10.21037/fomm-2020-tjddm-12

doi: $10.21037 /$ fomm-2020-tjddm-12

Cite this article as: Feinberg SE, Mercuri LG.

Temporomandibular joint disorders diagnosis and management-what does the future hold? Front Oral

Maxillofac Med 2020;2:25. 